Review

\title{
Blue Light in Dermatology
}

\author{
Magdalena Sadowska * ${ }^{\mathbb{C}}$, Joanna Narbutt and Aleksandra Lesiak
}

Department of Dermatology, Pediatric Dermatology and Dermatological Oncology, Medical University of Łódź, 90-419 Łódź, Poland; joanna.narbutt@umed.lodz.pl (J.N.); aleksandra.lesiak@umed.lodz.pl (A.L.)

* Correspondence: magdalena.sadowska.umed@gmail.com; Tel.: +48-505-959-159

\begin{abstract}
Phototherapy is an important method of dermatological treatments. Ultraviolet (280-400 nm) therapy is of great importance; however, there are concerns of its long-term use, as it can lead to skin aging and carcinogenesis. This review aims to evaluate the role and the mechanism of action of blue light (400-500 nm), a UV-free method. The main mediators of cellular responses to blue light are nitric oxide (NO) and reactive oxygen species (ROS). However, the detailed mechanism is still not fully understood. It was demonstrated that blue light induces an anti-inflammatory and antiproliferative effect; thus, it may be beneficial for hyperproliferative and chronic inflammatory skin diseases such as atopic dermatitis, eczema, and psoriasis. It was also found that blue light might cause the reduction of itching. It may be beneficial on hair growth and may be used in the treatment of acne vulgaris by reducing follicular colonization of Propionibacterium acnes. Further studies are needed to develop accurate protocols, as the clinical effects depend on the light parameters as well as the treatment length. There are no major adverse effects observed yet, but long-term safety should be monitored as there are no studies considering the long-term effects of blue light on the skin.
\end{abstract}

Keywords: blue light; phototherapy; dermatology

check for updates

Citation: Sadowska, M.; Narbutt, J.; Lesiak, A. Blue Light in Dermatology. Life 2021, 11, 670. https:/ / doi.org/ $10.3390 /$ life 11070670

Academic Editor: Enzo Berardesca

Received: 16 June 2021

Accepted: 6 July 2021

Published: 8 July 2021

Publisher's Note: MDPI stays neutral with regard to jurisdictional claims in published maps and institutional affiliations.

\section{Introduction}

Phototherapy is often used in the management of many common skin diseases. Its effect depends on wavelength, frequency, and the mechanism of action of light, but also on the irradiation time and the dose. The radiation spectrum includes infrared radiation (IR, 760-1000 nm), visible light (400-760 nm), and ultraviolet radiation (UV, 280-400 nm) [1,2]. The mechanism of action of visible light is not as fully understood as the widely used UVB. In the visible light spectrum there is red, orange, yellow, green, blue, and violet light. In this review we focus on better understanding of the role of blue light in dermatology. In recent years, the UV-free blue light phototherapy method (400-500 nm) has been attracting more attention. Despite the many advantages of UV treatment, there are some concerns of its long-term use, as it can lead to carcinogenesis and skin aging [3-7]. Therefore, there is a need to look for alternative, safer methods.

\section{The Mechanism of Action of Blue Light}

UVB interacts with cells of epidermis, whereas UVA reaches deeper layers of the skin and affects immune cells of epidermis and dermis [8]. Comparing with UV, visible light acts deeper in the dermis, but at the same time more superficially than infrared radiation. Hemoglobin and melanin of the epidermis are highly absorbing the visible light. The maximum penetration of blue light is $0.07-1 \mathrm{~mm}[1,9]$. Chromophores are the molecules that absorb light, such as in the following in the skin: endogenous nucleic acids, aromatic amino acids, urocanic acid, tryptophan, tyrosine, NADPH, NADH cofactors, cytochromes, riboflavins, porphyrins, melanin and melanin precursors, protoporphyrin IX, bilirubin, hemoglobin, $\beta$-carotene, or water molecules [1]. Therefore, the effect of blue light is dependent on different chromophores (photoacceptors). The main and the 
most important photoacceptors are opsins, flavins, porphyrins, and nitrosated proteins (e.g., S-nitro-albimin) [2].

It is suggested that blue light may affect mitochondrial function through cytochrome c oxidase, which is the complex IV of the electron transport chain, found in the mitochondrial membrane [10,11]. Dungel et al. demonstrated that blue light at the wavelength of $430 \mathrm{~nm}$ reactivates the mitochondrial respiratory function after inhibition with NO [10].

The role of opsin (OPN) (which are G-protein receptors) is also investigated as they are activated by blue light. Depending on location of their expression, there are different categories of opsins. OPN2, OPN3, and OPN4 are expressed in the epidermis [11]. The opsin receptor is possibly excited by blue light, stimulating the transient receptor potential channels and then causing a flood of calcium, which triggers calcium/calmodulin-dependent protein kinase-II (CAMKII) and in the end causes gene transcription changes [11]. OPN2 (Rhodopsin) and OPN3 (Panopsin, Encephalopsin) were found to be expressed not only in the skin, but also in the anagen hair follicle. Buscone et al. demonstrated that irradiation with blue light $\left(3.2 \mathrm{~J} / \mathrm{cm}^{2}, 453 \mathrm{~nm}\right)$ caused elongation of anagen phase in hair follicles ex vivo [12]. Opsin's role has also been investigated in the modulation of pigmentation and melanogenesis, but only in the Fitzpatrick skin type III and higher. It was found that blue light affects melanocytes directly and through OPN3 impacts the melanogenesis, which is calcium dependent. Blue light causes production of multimeric tyrosinase, which results in tyrosinase stimulation in melanocytes of the higher Fitzpatrick phototype [13].

Another potential mechanism of blue light includes the activation of flavins and flavoproteins. Flavin mononucleotide (FMN) and flavin adenine dinucleotide (FAD) exposed to irradiation increase reactive oxygen species (ROS) formation twofold [14]. In various cells, proteins that contains flavins can be found [2]. One of them is cryptochromes [15]. In a recent study, Buscone et al. suggested that blue light via cryptochrome 1 (CRY1) may induce a positive effect on hair growth, as it locates in the hair follicle after irradiation with $453 \mathrm{~nm}$. In ex vivo hair follicles, prolongation of the anagen phase was seen, which might be connected to the increase in the level of CRY1 during exposure to blue light [15].

Other blue light photoacceptors are porphyrins, which are heterocyclic aromatic compounds. Enzymes that contain porphyrin are present in various cells, such as hemoglobin, cytochrome p-450 enzymes, and the complexes of the electron transport chain [2,11]. It is suggested that irradiation with blue light by excitation of porphyrins leads to ROS formation [2,16-18] (Figure 1).

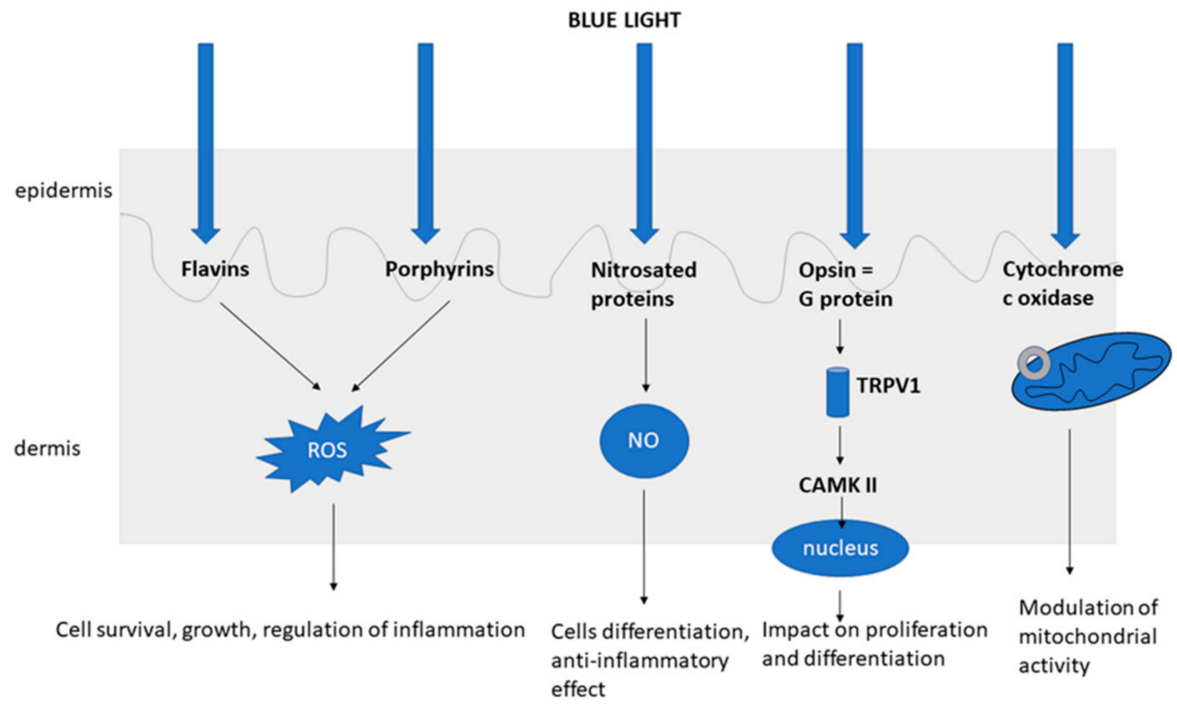

Figure 1. The mechanism of action of blue light $[2,10,11,14,16-21]$. 


\section{Antiproliferative and the Anti-Inflammatory Properties of Blue Light}

Becker et al. investigated the effect of blue light on keratinocytes and showed a reduction in the proliferation of these cells. In addition, increased oxidative stress was observed, which can be explained by the increased production of ROS in response to blue light irradiation. Physiologically reactive oxygen species are mainly produced in mitochondria in complex I and III of the electron transport chain [22]. The described effect depended on the exposure time, and a reduction in the proliferation of keratinocytes was observed after $15 \mathrm{~min}$ of irradiation. The study revealed an increase in the transcription of electron transport chain genes, cytochrome P450 genes, and steroid hormone genes. The authors, on the other hand, reported decreased expression of inflammation genes and suggested this was due to stimulation of steroid hormone production through the CYP pathway, which has anti-inflammatory effects [23].

Another explanation for decreased proliferation may be nitric oxide (NO)-mediated initiation of differentiation of keratinocytes [19]. Oplander et al. demonstrated that blue light $(\lambda=420$ and $\lambda=453 \mathrm{~nm})$ triggered NO production from S-nitroalbumin and aqueous nitrite solutions, but also resulted in an increase in free $\mathrm{NO}$ in the dermis in vivo [20]. Similarly, Mittermayr et al. observed the ability of blue light to detach NO from NO-hemoglobin compounds [24]. Yoo et al. found that blue light $\left(\lambda=470-480 \mathrm{~nm}, 76 \mathrm{~W} / \mathrm{m}^{2}\right)$ reduced the proliferation of human keratinocytes. Moreover, the authors observed a rise in the amount of TRPV1, which is one of the transient receptor potential (TRP) cation channels that is also observed in keratinocytes. It affects not only various signaling pathways, but also increases the level of pro-inflammatory cytokines and differentiation, and reduces proliferation. The authors demonstrated that the increase of TRPV1 caused EGFR destruction, which led to the inhibition of AKT/GSK3 $\beta$ /FoxO3a signaling, and in the end to the decrease of keratinocytes proliferation [25]. Thus, the main theory is that blue light via chromophores has an impact on proliferation and differentiation [23].

Various mechanisms are involved in ROS signaling. One of them is a Nrf2-dependent mechanism, which is a "basic leucine zipper protein" involved in the expression of antioxidant factors. By inhibiting NF-kB, which regulates the pro-inflammatory response, Nrf2 has an anti-inflammatory effect $[11,26]$. In the studies analyzing the influence of blue light on Nrf2 signaling, Trotter et al. observed upregulation of Nrf2 expression in vitro. In addition, the authors showed an effect on the inflammatory response of the human monocyte THP-1 cell line in response to blue light irradiation. Blue light reversed the cytotoxic effect of LPS (lipopolysaccharide), and irradiations decreased cytokine generation in response to $0.1 \mu \mathrm{g} / \mathrm{mL}$ LPS, but this effect was not observed at high LPS levels [26]. In the previous studies it was found that blue light treatment induced upregulation of Nrf2 in A431 epidermoid carcinoma cells and resulted in significantly increased levels of heme oxygenase 1 (HO-1), an anti-inflammatory and antioxidative factor [27]. These results may support the theory of the anti-inflammatory properties of blue light. Thus, it can be a therapeutic method in chronic inflammatory skin diseases.

The anti-inflammatory properties of blue light were also observed in other studies. Blue light irradiation $\left(\lambda=400-500 \mathrm{~nm}\right.$, at the intensities $3.75,7.5$, or $15 \mathrm{~J} / \mathrm{cm}^{2}$, total fluence $43.7 \mathrm{~J} / \mathrm{cm}^{2}$ ) of dendritic cells (DC) in vitro did not cause cell degradation. It reduced $\mathrm{DC}$ activation and maturation and decreased their effect on cytokine secretion by $\mathrm{T}$ cells, which produced a reduced amount of IFN- $\gamma$, IL-2, IL-10, IL-12p70, IL- $1 \beta$, and TNF- $\alpha$ (apart from IL-4) with the most effective results at higher doses. This indicates that the blue light has an anti-inflammatory effect [28]. Other findings have shown that blue light irradiations of monocyte-derived dendritic cells precursors (MDDCp) had no effect on monocyte-derived dendritic cell immature phenotype (iDCs) and did not affect the growth of mature dendritic cells. Thus, blue light did not affect differentiation and maturation of dendritic cells. However, the authors observed lower IL-6 and TNF-a generation by MDDCs dose dependently [29]. Kim et al. showed that the anti-inflammatory effect of blue light is NO and S-nitrosylation dependent and not by ROS [21]. Thus, blue light may be used for the treatment of hyperproliferative disorders and chronic inflammatory diseases. 


\section{The Negative Aspects of Blue Light}

J. Liebmann et al. found that blue light at $453 \mathrm{~nm}$ does not have a negative effect on human skin cells (keratinocytes and endothelial cells) up to a fluence of $500 \mathrm{~J} / \mathrm{cm}^{2}$ [19]. Similarly, Oplander et al. showed that blue light was nontoxic to human fibroblasts at $453 \mathrm{~nm}$, but also at $480 \mathrm{~nm}$. However, blue light at 410 and $420 \mathrm{~nm}$ caused increased oxidative stress as well as being toxic depending on the dose and wavelength. Moreover, small doses of blue light $(\lambda=410,420,453 \mathrm{~nm})$ decreased the antioxidative properties of fibroblasts. The authors demonstrated that fibroblasts may be more sensitive to blue light as a decrease in proliferation was observed after irradiations at 410, 420, and $453 \mathrm{~nm}$ at not toxic doses [30].

There are some studies showing the negative effect of blue light. Dong et al. observed that blue light at $410 \mathrm{~nm}$ caused a reduction in PER1 transcription in keratinocytes. It is a clock gene, involved in the circadian rhythm, which may suggest that skin cells are able to control the clock gene expression depending on the light sensation. The authors suggested that blue light may disrupt the nighttime rhythm of skin cells, which is important for the regeneration and repair. It can make cells feel like it is daytime at night. The PER1 level was reduced after $3 \mathrm{~h}$ in comparison to cells protected from the light. Additionally, they showed an increase in ROS production, DNA damage by $53 \%$, and inflammatory mediator production (IL- $1 \alpha$, IL-6, IL-8, and TNF- $\alpha$ ) after blue light irradiation. Exposure of human keratinocytes to $200 \mathrm{~J} / \mathrm{cm}^{2}$ (66 min) resulted in a $147 \%$ increase of ROS generation. Authors suggested that exposure to blue light may potentially cause skin damage and skin aging [31]. Similarly, Yoo et al. demonstrated that blue light caused a rise of ROS release, which was dependent on transient receptor potential vanilloid 1 (TRPV1). They also found that blue light increased proinflammatory cytokine TNF- $\alpha$ production by activating of activator protein $1(\mathrm{AP}-1)$ and nuclear factor $\mathrm{\kappa B}(\mathrm{NF}-\mathrm{kB})$ [25]. In the study investigating the ROS formation following phototherapy, Nakashima et al. found that blue light caused oxidative stress in human keratinocytes. The effect was greater after UVA irradiations than the blue light. Blue light through flavin excitation caused production of ROS, probably superoxide, which may promote skin aging, whereas UVA induced formation of singlet oxygen [32]. Vandersee et al. observed that blue-violet light irradiation of the skin $(80 \%$ in $380-495 \mathrm{~nm}$, maxima $440 \mathrm{~nm}, 100 \mathrm{~mW} / \mathrm{cm}^{2}$ ) induced destruction of the carotenoids dose dependently. These antioxidants were reduced by $13.5 \%$ after irradiation at $50 \mathrm{~J} / \mathrm{cm}^{2}$ and $21.2 \%$ after irradiation at $100 \mathrm{~J} / \mathrm{cm}^{2}$. Their levels returned to the original level after $1 \mathrm{~h}$ for the dose of $50 \mathrm{~J} / \mathrm{cm}^{2}$ and $24 \mathrm{~h}$ for the dose of $100 \mathrm{~J} / \mathrm{cm}^{2}$. The authors suggested that the destruction of dermal carotenoids indicates the number of produced free radicals, mainly ROS in the skin [33].

Liebmann et al. found that blue light $(\lambda=412, \lambda=419$, and $\lambda=426 \mathrm{~nm}$ at high fluences $66-100 \mathrm{~J} / \mathrm{cm}^{2}$ and $\lambda=453 \mathrm{~nm}$ at very high fluences $\left.>500 \mathrm{~J} / \mathrm{cm}^{2}\right)$ is toxic for endothelial cells and keratinocytes. After three consecutive days of irradiation every $24 \mathrm{~h}$, the amount of endothelial cells and keratinocytes were decreased in cultures irradiated with 412, 419, or $426 \mathrm{~nm}$ compared to the nonirradiated cells. This was dependent on the dose as well as the wavelength. On the other hand, blue light at $453 \mathrm{~nm}$ up to fluence of $500 \mathrm{~J} / \mathrm{cm}^{2}$ was not toxic [19]. However, in the recent study it was reported that in keratinocytes, no apoptosis occurred $24 \mathrm{~h}$ after $30 \mathrm{~min}$ irradiation with blue light $\left(\lambda=453 \mathrm{~nm}, 23 \mathrm{~mW} / \mathrm{cm}^{2}\right)$. The authors investigated the impact of blue light on ROS release, apoptosis, and gene expression after irradiation of human keratinocytes in vitro. A rise in ROS amount was observed $30 \mathrm{~min}$ after irradiation, which returned to its original levels already $1 \mathrm{~h}$ after irradiation. Moreover, the induction of ROS production did not destroy the cells, and apoptosis was not detected. Analyzing gene expression after blue light irradiation, its effect could be seen already after $1 \mathrm{~h}$. The authors discovered the aryl hydrocarbon receptor, which could be a target for blue light, as at certain doses it might act in a cell protective manner, accompanied with reduced proliferation, production of steroid hormones, and inhibition of inflammatory responses. It is possible that the mechanism responsible for AHR activation may be the photo-oxidation of tryptophan by blue light [34]. 
Therefore, blue light at $453 \mathrm{~nm}$ using an intensity of $23 \mathrm{~mW} / \mathrm{cm}^{2}$ and up to fluence of $500 \mathrm{~J} / \mathrm{cm}^{2}$ does not cause apoptosis of keratinocytes, whereas T cells are susceptible to apoptosis at lower energy levels, with the fluences that are not toxic for keratinocytes and endothelial cells $[19,34]$. While small amounts of ROS may protect the cells, larger amounts of ROS can damage them [35]. However, there is a theory that the viability of cells depends on their mechanisms to deal with oxidative stress [30]. Wataha et al. found that blue light modulates cell survival and growth in different ways, and it depends on how much energy the cells use. Rapidly dividing cells, requiring more energy, were more sensitive to the inhibitory effects of blue light, but it is still unknown how exactly [36].

In the case of UV irradiation, there are confirmed long-term side effects such as skin aging and carcinogenesis [3-7]. Considering the risks of UV treatments, blue light seems to be a safer therapeutic option. However, as it is an innovative method, long-term safety should be monitored.

\section{Effect on Pigmentation}

Duteil et al. analyzed the influence of blue $(\lambda=415 \mathrm{~nm})$ and red light $(\lambda=630 \mathrm{~nm})$ on the increase in pigmentation in vivo and found correlation with blue light spectrum in patients with III and IV skin phototype. Moreover, the hyperpigmentation persisted during the 3-month follow-up and was more intense compared to patients exposed to UVB. This effect was not observed considering the red light. However, the mechanism behind this phenomenon is unknown [37]. Hyperpigmentation was also observed in other clinical studies [38-40]. In patients with psoriasis vulgaris treated with blue light $(\lambda=420 \mathrm{~nm}$ and $453 \mathrm{~nm}$ ), the only side effect observed was hyperpigmentation in $50 \%$ of the patients, which was not permanent and it disappeared after treatment was finished [39]. In another study of patients with psoriasis, hyperpigmentation was reported in $80 \%$ of subjects after blue light irradiation [40]. Kleinpenning et al. analyzed skin biopsies of patients with no skin lesions after 5 days of blue light irradiations (Waldmann 450L photodynamic therapy lamp, $20 \mathrm{~J} / \mathrm{cm}^{2}$ two times a day) and a mild hyperpigmentation was noted, confirmed by Melan-A-positive cells found in the skin exposed to blue light. However, no impact on DNA damage of skin cells, early photoaging, and inflammatory cell infiltration was seen [41].

\section{Anticancer Effect}

There are some studies in vitro that demonstrated the anticancer effect of blue light. Ohara et al. demonstrated that blue light $\left(\lambda=470 \mathrm{~nm}\right.$, irradiance $\left.5.7 \mathrm{~mW} / \mathrm{cm}^{2}\right)$ inhibited the growth of B16 melanoma cells, which was related to the irradiation time; however, no rise of apoptosis was observed. The number of G0/G1- and G2/M-phase cells was higher and the number of S-phase cells was lower after irradiations, although the exact mechanism is not known [42]. In the next studies, Ohara et al. showed that adding riboflavin to the B16 melanoma cells exposed to blue light $\left(\lambda=470 \mathrm{~nm}\right.$, irradiance $\left.5.7 \mathrm{~mW} / \mathrm{cm}^{2}\right)$ induced cell damage. This effect was not observed after irradiation with green or red light, indicating the influence of ROS was generated due to the absorption of blue light by riboflavin [43]. Thus, combining blue light with photosensitizing factors may increase the effectiveness of photodynamic therapy (PDT). Similarly, Sparsa et al. found that irradiation with blue light of B16F10 melanoma and bovine endothelial cells $\left(\lambda=450 \mathrm{~nm}, 10 \mathrm{~J} / \mathrm{cm}^{2}\right)$ caused cell necrosis. Suspecting that this phenomenon could be triggered by ROS production, the authors monitored the oxidative stress of the cells. However, no effect was observed at $10 \mathrm{~J} / \mathrm{cm}^{2}$ or $20 \mathrm{~J} / \mathrm{cm}^{2}$, suggesting that a different mechanism was responsible for cell damage [44]. In the recent study, Chen et al. showed the suppressive effect of blue light $(\lambda=418 \mathrm{~nm}$ and $457 \mathrm{~nm})$ on the growth of melanoma. The wavelength $457 \mathrm{~nm}$ was more effective in inhibiting the growth and migration of B16F10 melanoma cells. Since in OPN3, one of the photoreceptors absorbs blue light with a wavelength of $460 \mathrm{~nm}$, it is suspected that it may be involved in the cytostatic effect of blue light. Moreover, the inhibitory effect was stronger when high irradiation was used $(0.04,0.07,0.14,0.22,0.30,0.37,0.45,0.56$, or 
$\left.1.12 \mathrm{~J} / \mathrm{cm}^{2}\right)$. The authors found that higher irradiance $\left(0.93 \mathrm{~mW} / \mathrm{cm}^{2}\right)$ resulted in a greater increase in ROS production and impairment of mitochondrial membrane potential (MMP) than lower irradiance $\left(0.31 \mathrm{~mW} / \mathrm{cm}^{2}\right)[45]$.

\section{The Clinical Use of Blue Light}

Because of anti-inflammatory and antiproliferative properties of blue light, it may be beneficial for chronic inflammatory skin diseases such as psoriasis vulgaris, atopic dermatitis, and eczema. However, the number of studies assessing the efficacy of blue light treatment in these entities is limited.

\subsection{Psoriasis}

There are six clinical studies assessing the use of blue light in the treatment of psoriasis vulgaris. No major side effects were observed. Only one study did not show the effectiveness of blue light [39,40,46-49]. Maari et al. treated 17 patients with plaque psoriasis with blue light $\left(\lambda=417 \mathrm{~nm}, 10 \mathrm{~J} / \mathrm{cm}^{2}, 8.5 \mathrm{~mW} / \mathrm{cm}^{2}\right)$ three times per week for 4 weeks. After 4 weeks, no improvement was observed in the mean psoriasis severity scores of the irradiated plaques [46]. In the prospective, randomized, double-blind study, a statistically significant improvement was demonstrated in the treatment of psoriasis vulgaris using blue light irradiations. Two groups of patients $\left(\lambda=420 \mathrm{~nm}\right.$ and $\left.453 \mathrm{~nm}, 90 \mathrm{~J} / \mathrm{cm}^{2}, 100 \mathrm{~mW} / \mathrm{cm}^{2}\right)$ participated in irradiations each day $(15 \mathrm{~min})$ for 4 weeks. The significant improvement of the Local Psoriasis Severity Index (LPSI) was seen in both groups [39]. Probably comparing to the previous study, the better effect was achieved because of the use of higher doses $\left(90 \mathrm{~J} / \mathrm{cm}^{2}\right.$ vs. $\left.10 \mathrm{~J} / \mathrm{cm}^{2}\right)$ and the higher number of irradiations (seven per week vs. three per week). In the next prospective, randomized, double-blind study analyzing two groups of patients (low-intensity and high-intensity group), the therapeutic efficacy of blue light $\left(\lambda=453 \mathrm{~nm}, 100 \mathrm{~mW} / \mathrm{cm}^{2}\right.$ vs. $\left.200 \mathrm{~mW} / \mathrm{cm}^{2}\right)$ was observed after 12 weeks and compared to the control in both groups. Moreover, in patients receiving a higher intensity of blue light, a significant improvement of LPSI symptoms compared with the control group was demonstrated at each study period. Complete resolution of psoriatic lesions was observed in two patients, which was not achieved in the previous study. This may indicate that longer treatment of blue light is more effective (12 weeks vs. 4 weeks) [47]. Kleinpenning et al. showed that the use of $10 \%$ salicylic acid in petrolatum with blue light $(\lambda=420 \mathrm{~nm}$, $100 \mathrm{~mW} / \mathrm{cm}^{2}$ ), as well as with red light, caused a statistically significant improvement in the clinical plaque severity scores within 4 weeks of treatment of 20 patients with psoriasis vulgaris. As severe scaling makes light penetration more difficult, salicylic acid was used to remove the plaques. Moreover, there is a hypothesis that, because of the presence of an endogenous photosensitizer-protoporphyrin IX (PPIX) in psoriatic plaques, photodynamic therapy may be a promising therapeutic option even without aminolevulinic acid application [40]. In a recent prospective, randomized study, Krings et al. investigated the effectiveness of blue light $\left(\lambda=453 \mathrm{~nm}\right.$, high irradiance level $600 \mathrm{~mW} / \mathrm{cm}^{2}, 15 \mathrm{~min}$ and 30 $\mathrm{min}$ ) in the treatment of mild psoriasis vulgaris. It was compared to the standard topical calcipotriol, showing similar effectiveness. Both groups (15 min vs. $30 \mathrm{~min}$ ) achieved a statistically significant improvement of approximately 50\% after 12 weeks of treatment preformed each day. Thus, different fluences $\left(38 \mathrm{~J} / \mathrm{cm}^{2}\right.$ in $15 \mathrm{~min}$ and $76 \mathrm{~J} / \mathrm{cm}^{2}$ in $30 \mathrm{~min}$ ) caused a similar effect [48]. This indicates that the improvement of the blue light treatment depends not only on the fluence and intensity of irradiations, but also on the total length of treatment and the length of each cycle. Higher fluence, intensity, and longer total treatment time resulted in better outcomes (Table 1). However, in the recent study, the authors demonstrated that extension of duration of irradiation with higher fluencies did not lead to the improvement in effectiveness [48]. The positive effects of blue light were also confirmed in the prospective clinical study of 30 patients with a mild psoriasis vulgaris. The evaluation of the effectiveness of local blue light treatment showed a statistically significant improvement in the mean LPSI and DLQI [49]. 
Table 1. Blue light in psoriasis vulgaris, atopic dermatitis, and eczema.

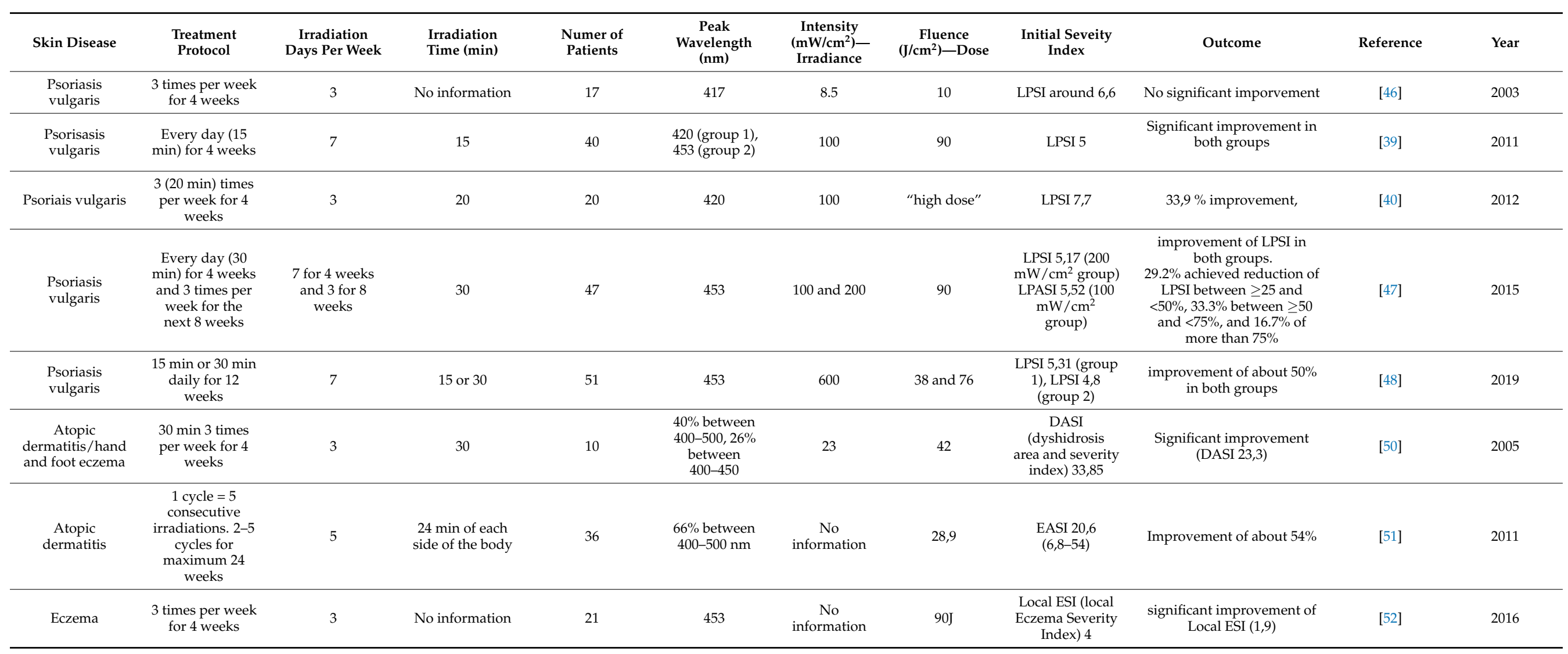




\subsection{Atopic Dermatitis and Eczema}

There are only three studies investigating the use of blue light in the treatment of atopic dermatitis and eczema. In a study of 10 patients with atopic dermatitis/hand and foot eczema, focal blue light ( $40 \%$ between 400 and $500 \mathrm{~nm}, 26 \%$ between 400 and $450 \mathrm{~nm}$, $42 \mathrm{~J} / \mathrm{cm}^{2}, 30 \mathrm{~min}$ three times per week for 4 weeks) was shown to cause a significant clinical improvement (Dyshidrosis Area and Severity Index (DASI) before 34.9 vs. after 23.3) compared to the control irradiations (DASI before 32.8 vs. after 34.9) [50]. In another study, 36 adult patients with severe, chronic atopic dermatitis attended full body blue light irradiation $\left(66 \%\right.$ between 400 and $\left.500 \mathrm{~nm}, 28.9 \mathrm{~J} / \mathrm{cm}^{2}\right)$. In total, between two and five cycles (five daily irradiations) were performed over a 6-month period, and between cycles the patients used topical corticosteroids. At 15 days, and at 3 and 6 months after starting the study, a decrease of disease severity (EASI) was observed of $29 \%, 41 \%$, and $54 \%$, respectively. Reduction in the severity of itching was one of the initial symptoms of improvement that occurred. In addition, the authors showed improvements in sleep quality and quality of life [51]. Additionally, in the prospective, randomized study, it was shown that blue light $\left(\lambda=453 \mathrm{~nm}, 90 \mathrm{~J} / \mathrm{cm}^{2}\right)$ used locally was safe and induced an improvement in eczema lesions [52].

\subsection{Acne}

There is an increasing number of studies demonstrating the beneficial effects of blue light treatment in acne vulgaris [53-60]. The main hypothesis is that the positive effect is related to the reduction of follicular colonization of Propionibacterium acnes, which may be related to the activation of endogenous bacterial porphyrins by blue light [61]. The most important clinical trials are included in Table 2. In the study analyzing the impact of blue light $(\lambda=415 \mathrm{~nm})$ and red light $(\lambda=630 \mathrm{~nm})$ on lipid formation, blue light significantly inhibited sebocyte proliferation depending on the dose. This effect was only minimal when analyzing red light. However, based on a lipogenesis study, it was demonstrated that $630 \mathrm{~nm}$ light downregulated lipid production. This phenomenon that blue and red light may interfere with lipid generation in sebocytes suggests positive potential in the treatment of acne by inhibiting sebum formation [62].

\subsection{Photodynamic Therapy (PDT)}

A method of treatment that uses visible light, including blue light, is photodynamic therapy. It is mainly used for nonmelanoma skin cancers and actinic keratosis, but the list of indications is enlarging. It is necessary to apply a photosensitizing substance followed by a light irradiation [63-67]. The reaction between the photosensitizer and light leads to the formation of cytotoxic reactive oxygen species (ROS), and as a result, to the destruction of targeted cells $[68,69]$. The most commonly used topical substances are 5-aminolevulinic acid (5-ALA) and metyl-aminolevulinate (MAL), which are then metabolated to protoporphyrin IX (PPIX) [66]. The spectrum between 400 and $700 \mathrm{~nm}$ causes photoexcitation of PPIX and the highest peak is at blue light $(\lambda=405 \mathrm{~nm})[66,70]$. However, the penetration of blue light into the skin is more superficial than the penetration of red light [67]. As a consequence, only red light is used to treat skin cancers, whereas blue light may be used for the nonhyperkeratotic actinic keratosis therapy $[63,64,71]$. 
Table 2. Blue light in acne vulgaris.

\begin{tabular}{|c|c|c|c|c|c|c|c|}
\hline Skin Disorder & Treatment Protocol & $\begin{array}{c}\text { Irradiation Days Per } \\
\text { Week }\end{array}$ & Irradiation Time & $\begin{array}{l}\text { Wavelength, } \\
\text { Intensity }\end{array}$ & Number of Patients & Outcome & Reference \\
\hline $\begin{array}{l}\text { Acne vulgaris (mild } \\
\text { to moderate, facial, } \\
\text { inflammatory) }\end{array}$ & $\begin{array}{c}\text { every other } \\
\text { day for } 8 \text { weeks, with } \\
\text { final assessment } 4 \\
\text { weeks } \\
\text { post-treatment. }\end{array}$ & 7 & No information & $414 \mathrm{~nm}$ & $\begin{array}{l}26 \text { (treatment group), } \\
15 \text { (control group) }\end{array}$ & $\begin{array}{c}\text { Reduction of } \\
\text { inflammatory lesion } \\
\text { by } 50.02 \% \text {. } \\
\text { Maximum effect at } \\
\text { week } 8-12 \text {. After } \\
\text { week } 12 \text { all patients } \\
\text { achieved } \\
\text { improvement. }\end{array}$ & [53] \\
\hline $\begin{array}{l}\text { Acne vulgaris (mild } \\
\text { to moderate) }\end{array}$ & $\begin{array}{c}\text { twice a week, } \\
\text { with an interval of } \\
\text { two days, for } 4 \text { weeks }\end{array}$ & 2 & $20 \mathrm{~min}$ & $\begin{array}{c}405+/-10 \mathrm{~nm} \text { blue } \\
\text { light } \\
\text { at the power of } 30 \\
\mathrm{~mW} / \mathrm{cm}^{2}\end{array}$ & $\begin{array}{l}10 \text { (blue light), } 10 \\
\text { (red light) }\end{array}$ & $\begin{array}{c}\text { Reduction of lesions } \\
\text { by } 71.4 \% \text {. } \\
\text { The mean number of } \\
\text { lesions decreased } \\
\text { from } 19.2 \text { to } 5.5 \text { after } \\
8 \text { irradiations. }\end{array}$ & [54] \\
\hline Acne vulgaris & $\begin{array}{c}\text { twice a week up to } 5 \\
\text { weeks }\end{array}$ & 2 & No information & $\begin{array}{c}407-420 \mathrm{~nm}, 90 \\
\mathrm{~mW} / \mathrm{cm}^{2}\end{array}$ & 30 & $\begin{array}{c}\text { Reduction of lesions } \\
\text { by } 64 \% \text {. Within week } \\
577 \% \text { of patients } \\
\text { achieved } \\
\text { improvement. }\end{array}$ & [55] \\
\hline Acne vulgaris & $\begin{array}{c}\text { once or } \\
\text { twice a week. }\end{array}$ & $1-2$ & $\begin{array}{c}30 \mathrm{~min} \text { (face), } 45 \mathrm{~min} \\
\text { (back) }\end{array}$ & $\begin{array}{c}405 \\
\text { and } 420 \mathrm{~nm}\end{array}$ & 10 & $\begin{array}{l}\text { Improvement was } \\
\text { observed in } 80 \% \text { of } \\
\text { patients }\end{array}$ & [56] \\
\hline $\begin{array}{c}\text { Acne vulgaris (mild } \\
\text { to moderate facial } \\
\text { acne) }\end{array}$ & $\begin{array}{l}\text { twice a week for } 4 \\
\text { weeks }\end{array}$ & 2 & $14 \mathrm{~min}$ & $\begin{array}{c}415-425 \mathrm{~nm} \text { (peak } \\
420 \mathrm{~nm})\end{array}$ & 21 & $\begin{array}{l}\text { Significant reduction } \\
\text { of lesions }\end{array}$ & [57] \\
\hline $\begin{array}{l}\text { Acne vulgaris (facial } \\
\text { acne) }\end{array}$ & $\begin{array}{c}\text { Twice a week for } 4 \\
\text { weeks }\end{array}$ & 2 & $15 \mathrm{~min}$ & $420 \mathrm{~nm}$ & 28 & $\begin{array}{c}\text { Lesions improved by } \\
64.7 \%\end{array}$ & [58] \\
\hline $\begin{array}{c}\text { Acne vulgaris } \\
\text { (mild-to-moderate } \\
\text { inflammatory acne } \\
\text { on the face) }\end{array}$ & $\begin{array}{c}\text { Once a day for } 8 \\
\text { weeks }\end{array}$ & 7 & $6 \mathrm{~min}$ & $414 \mathrm{~nm}$ & 21 & $\begin{array}{l}\text { Reduction of open } \\
\text { and closed } \\
\text { comedomes, papules }\end{array}$ & [59] \\
\hline $\begin{array}{l}\text { Acne vulgaris (mild } \\
\text { to moderate) }\end{array}$ & $\begin{array}{c}\text { Twice a week for } 4 \\
\text { weeks }\end{array}$ & 2 & $10 / 20 \mathrm{~min}$ & $\begin{array}{c}409-419 \mathrm{~nm} \text { at } 40 \\
\mathrm{~mW} / \mathrm{cm}^{2}\end{array}$ & 30 & $\begin{array}{l}\text { Reduction of lesions } \\
\text { (at week 8-12) }\end{array}$ & {$[60]$} \\
\hline
\end{tabular}




\section{Conclusions}

Phototherapy is an important method of dermatological treatments. The main factors responsible for biological changes induced by blue light are light parameters. Developing accurate protocols is crucial, as clinical effects are not only related to the duration of the treatment, but also to the dose and intensity of irradiations. The main factors involved in the response of cells to blue light are NO and ROS. However, the detailed mechanism is still not fully understood. It was demonstrated that blue light induces an anti-inflammatory and antiproliferative effect; thus, it may be beneficial for chronic inflammatory skin diseases such as atopic dermatitis, eczema, and psoriasis. Additionally, the positive effect on the treatment of acne vulgaris and on hair growth was also shown. Another beneficial effect is the reduction of itching, observed in some studies, which may be of great importance in the treatment of patients with skin diseases. On the other hand, there are some studies indicating the negative effects of blue light such as increased oxidative stress, reduced antioxidative capacity of fibroblasts, desynchronization of the cells' nighttime rhythm, and increased inflammatory response; thus, there are some conflicting results. It seems that this method is safe and the only observed clinical adverse effect may be transient hyperpigmentation. However, there are no studies considering the long-term effects of blue light on the skin.

Author Contributions: Conceptualization, M.S. and A.L.; methodology, M.S.; software, M.S.; validation, A.L., J.N. and M.S.; formal analysis, J.N.; investigation, M.S.; resources, M.S.; data curation, M.S.; writing—original draft preparation, M.S.; writing—review and editing, J.N., A.L. and M.S.; visualization, M.S.; supervision, A.L.; project administration, A.L.; funding acquisition, M.S. and A.L. All authors have read and agreed to the published version of the manuscript.

Funding: This research was funded by statutory activities of Medical University of Lodz no. 503/5064-04/503-01.

Institutional Review Board Statement: Not applicable.

Informed Consent Statement: Not applicable.

Data Availability Statement: No new data were created or analyzed in this study. Data sharing is not applicable to this article.

Conflicts of Interest: The authors declare no conflict of interest.

\section{References}

1. Sowa, P.; Rutkowska-Talipska, J.; Rutkowski, K.; Kosztyła-Hojna, B.; Rutkowski, R. Optical Radiation in Modern Medicine. Adv. Dermatol. Allergol. 2013, 4, 246-251. [CrossRef]

2. Garza, Z.C.F.; Born, M.; Hilbers, P.A.J.; Riel, N.A.W.V.; Liebmann, J. Visible Blue Light Therapy: Molecular Mechanisms and Therapeutic Opportunities. Curr. Med. Chem. 2019, 25, 5564-5577. [CrossRef] [PubMed]

3. Menter, A.; Korman, N.J.; Elmets, C.A.; Feldman, S.; Gelfand, J.; Gordon, K.B.; Gottlieb, A.; Koo, J.Y.; Lebwohl, M.; Lim, H.W.; et al. Guidelines of Care for the Management of Psoriasis and Psoriatic Arthritis. J. Am. Acad. Dermatol. 2010, 62, 114-135. [CrossRef]

4. Archier, E.; Devaux, S.; Castela, E.; Gallini, A.; Aubin, F.; Le Maître, M.; Aractingi, S.; Bachelez, H.; Cribier, B.; Joly, P.; et al. Carcinogenic Risks of Psoralen UV-A Therapy and Narrowband UV-B Therapy in Chronic Plaque Psoriasis: A Systematic Literature Review. J. Eur. Acad. Dermatol. Venereol. 2012, 26, 22-31. [CrossRef] [PubMed]

5. Lindelöf, B.; Sigurgeirsson, B.; Tegner, E.; Larkö, O.; Johannesson, A.; Berne, B.; Ljunggren, B.; Andersson, T.; Molin, L.; NylanderLundqvist, E.; et al. PUVA and Cancer Risk: The Swedish Follow-up Study. Br. J. Dermatol. 1999, 141, 108-112. [CrossRef] [PubMed]

6. Brieva, A.; Guerrero, A.; Pivel, J.P. Incidence and risk factors associated with a second squamous cell carcinoma or basal cell carcinoma in psoralen + ultraviolet light-treated psoriasis patients. J. Investig. Dermatol. 2002, 118, 1038-1043. [CrossRef]

7. Stern, R.S. The Risk of Squamous Cell and Basal Cell Cancer Associated With Psoralen and Ultraviolet A Therapy: A 30-Year Prospective Study. J. Am. Acad. Dermatol. 2012, 66, 553-562. [CrossRef] [PubMed]

8. Schneider, L.A.; Hinrichs, R.; Scharffetter-Kochanek, K. Phototherapy and Photochemotherapy. Clin. Dermatol. 2008, 26, 464-476. [CrossRef]

9. Ash, C.; Dubec, M.; Donne, K.; Bashford, T. Effect of Wavelength and Beam Width on Penetration in Light-Tissue Interaction Using Computational Methods. Lasers Med Sci. 2017, 32, 1909-1918. [CrossRef] 
10. Dungel, P.; Mittermayr, R.; Haindl, S.; Osipov, A.; Wagner, C.; Redl, H.; Kozlov, A.V. Illumination With Blue Light Reactivates Respiratory Activity of Mitochondria Inhibited by Nitric Oxide, But Not by Glycerol Trinitrate. Arch. Biochem. Biophys. 2008, 471, 109-115. [CrossRef]

11. Serrage, H.; Heiskanen, V.; Palin, W.M.; Cooper, P.R.; Milward, M.R.; Hadis, M.; Hamblin, M.R. Under the Spotlight: Mechanisms of Photobiomodulation Concentrating on Blue and Green Light. Photochem. Photobiol. Sci. 2019, 18, 1877-1909. [CrossRef] [PubMed]

12. Buscone, S.; Mardaryev, A.; Raafs, B.; Bikker, J.W.; Sticht, C.; Gretz, N.; Farjo, N.; Uzunbajakava, N.E.; Botchkareva, N.V. A New Path in Defining Light Parameters for Hair Growth: Discovery and Modulation of Photoreceptors in Human Hair Follicle. Lasers Surg. Med. 2017, 49, 705-718. [CrossRef] [PubMed]

13. Regazzetti, C.; Sormani, L.; Debayle, D.; Bernerd, F.; Tulic, M.; De Donatis, G.M.; Chignon-Sicard, B.; Rocchi, S.; Passeron, T. Melanocytes Sense Blue Light and Regulate Pigmentation through Opsin-3. J. Investig. Dermatol. 2018, 138, 171-178. [CrossRef]

14. Yang, M.-Y.; Chang, C.-J.; Chen, L.-Y. Blue Light Induced Reactive Oxygen Species from Flavin Mononucleotide and Flavin Adenine Dinucleotide on Lethality of HeLa Cells. J. Photochem. Photobiol. B Biol. 2017, 173, 325-332. [CrossRef]

15. Buscone, S.; Mardaryev, A.N.; Westgate, G.E.; Uzunbajakava, N.E.; Botchkareva, N.V. Cryptochrome 1 Is Modulated by Blue Light in Human Keratinocytes and Exerts Positive Impact on Human Hair Growth. Exp. Dermatol. 2021, 30, 271-277. [CrossRef]

16. Maclean, M.; McKenzie, K.; Anderson, J.; Gettinby, G.; MacGregor, S. 405 Nm Light Technology for the Inactivation of Pathogens and Its Potential Role for Environmental Disinfection and Infection Control. J. Hosp. Infect. 2014, 88, 1-11. [CrossRef]

17. MacLean, M.; MacGregor, S.; Anderson, J.; Woolsey, G. The Role of Oxygen in the Visible-Light Inactivation of Staphylococcus Aureus. J. Photochem. Photobiol. B Biol. 2008, 92, 180-184. [CrossRef]

18. Dai, T.; Gupta, A.; Murray, C.K.; Vrahas, M.S.; Tegos, G.P.; Hamblin, M.R. Blue Light for Infectious Diseases: Propionibacterium Acnes, Helicobacter Pylori, and Beyond? Drug Resist. Updat. 2012, 15, 223-236. [CrossRef]

19. Liebmann, J.; Born, M.; Kolb-Bachofen, V. Blue-Light Irradiation Regulates Proliferation and Differentiation in Human Skin Cells. J. Investig. Dermatol. 2010, 130, 259-269. [CrossRef]

20. Opländer, C.; Deck, A.; Volkmar, C.M.; Kirsch, M.; Liebmann, J.; Born, M.; van Abeelen, F.; van Faassen, E.E.; Kröncke, K.D.; Windolf, J.; et al. Mechanism and Biological Relevance of Blue-Light (420-453 Nm)-Induced Nonenzymatic Nitric Oxide Generation from Photolabile Nitric Oxide Derivates in Human Skin in Vitro and in Vivo. Free Radic. Biol. Med. 2013, 65, 1363-1377. [CrossRef] [PubMed]

21. Kim, H.-J.; Choi, M.S.; Bae, I.-H.; Jung, J.-Y.; Son, E.D.; Lee, T.R.; Shin, D.W. Short Wavelength Visible Light Suppresses Innate Immunity-Related Responses by Modulating Protein S-Nitrosylation in Keratinocytes. J. Investig. Dermatol. 2016, 136, 727-731. [CrossRef] [PubMed]

22. Holmström, K.M.; Finkel, T. Cellular Mechanisms and Physiological Consequences of Redox-Dependent Signalling. Nat. Rev. Mol. Cell Biol. 2014, 15, 411-421. [CrossRef] [PubMed]

23. Becker, A.; Sticht, C.; Dweep, H.; Van Abeelen, F.A.; Gretz, N.; Oversluizen, G. Impact of Blue LED Irradiation on Proliferation and Gene Expression of Cultured Human Keratinocytes. Mech. Low Light Ther. X 2015, 9309, 930909. [CrossRef]

24. Mittermayr, R.; Osipov, A.; Piskernik, C.; Haindl, S.; Dungel, P.; Weber, C.; Vladimirov, Y.A.; Redl, H.; Kozlov, A.V. Blue Laser Light Increases Perfusion of a Skin Flap Via Release of Nitric Oxide from Hemoglobin. Mol. Med. 2007, 13, 22-29. [CrossRef]

25. Yoo, J.A.; Yu, E.; Park, S.-H.; Oh, S.W.; Kwon, K.; Park, S.J.; Kim, H.; Yang, S.; Park, J.Y.; Cho, J.Y.; et al. Blue Light Irradiation Induces Human Keratinocyte Cell Damage via Transient Receptor Potential Vanilloid 1 (TRPV1) Regulation. Oxidative Med. Cell. Longev. 2020, 2020, 1-14. [CrossRef]

26. Trotter, L.A.; Patel, D.; Dubin, S.; Guerra, C.; McCloud, V.; Lockwood, P.; Messer, R.; Wataha, J.C.; Lewis, J.B. Violet/Blue Light Activates Nrf2 Signaling and Modulates the Inflammatory Response of THP-1 Monocytes. Photochem. Photobiol. Sci. 2017, 16, 883-889. [CrossRef]

27. Patel, A.D.; Rotenberg, S.; Messer, R.L.W.; Wataha, J.C.; Ogbureke, K.; McCloud, V.V.; Lockwood, P.; Hsu, S.; Lewis, J.B. Blue Light Activates Phase 2 Response Proteins and Slows Growth of a431 Epidermoid Carcinoma Xenografts. Anticancer Res. 2014, 34 , 6305-6313.

28. Fischer, M.R.; Abel, M.; Kostka, S.L.; Rudolph, B.; Becker, D.; Von Stebut, E. Blue Light Irradiation Suppresses Dendritic Cells Activationin Vitro. Exp. Dermatol. 2013, 22, 558-560. [CrossRef] [PubMed]

29. Monfrecola, G.; Lembo, S.; Cantelli, M.; Ciaglia, E.; Scarpato, L.; Fabbrocini, G.; Balato, A. The Effect of Visible Blue Light on the Differentiation of Dendritic Cells in Vitro. Biochimie 2014, 101, 252-255. [CrossRef]

30. Opländer, C.; Hidding, S.; Werners, F.B.; Born, M.; Pallua, N.; Suschek, C.V. Effects of Blue Light Irradiation on Human Dermal Fibroblasts. J. Photochem. Photobiol. B Biol. 2011, 103, 118-125. [CrossRef] [PubMed]

31. Dong, K.; Goyarts, E.C.; Pelle, E.; Trivero, J.; Pernodet, N. Blue Light Disrupts the Circadian Rhythm and Create Damage in Skin Cells. Int. J. Cosmet. Sci. 2019, 41, 558-562. [CrossRef]

32. Nakashima, Y.; Ohta, S.; Wolf, A.M. Blue Light-Induced Oxidative Stress in Live Skin. Free Radic. Biol. Med. 2017, 108, 300-310. [CrossRef] [PubMed]

33. Vandersee, S.; Beyer, M.; Lademann, J.; Darvin, M.E. Blue-Violet Light Irradiation Dose Dependently Decreases Carotenoids in Human Skin, Which Indicates the Generation of Free Radicals. Oxidative Med. Cell. Longev. 2015, 2015, 1-7. [CrossRef] [PubMed] 
34. Becker, A.; Klapczynski, A.; Kuch, N.; Arpino, F.; Simon-Keller, K.; De La Torre, C.; Sticht, C.; Van Abeelen, F.A.; Oversluizen, G.; Gretz, N. Gene Expression Profiling Reveals Aryl Hydrocarbon Receptor As a Possible Target for Photobiomodulation When Using Blue Light. Sci. Rep. 2016, 6, 1-11. [CrossRef]

35. Ristow, M. Unraveling the Truth About Antioxidants: Mitohormesis Explains ROS-Induced Health Benefits. Nat. Med. 2014, 20, 709-711. [CrossRef]

36. Wataha, J.; Lewis, J.; Lockwood, P.; Hsu, S.; Messer, R.; Rueggeberg, F.; Bouillaguet, S. Blue Light Differentially Modulates Cell Survival and Growth. J. Dent. Res. 2004, 83, 104-108. [CrossRef]

37. Duteil, L.; Cardot-Leccia, N.; Queille-Roussel, C.; Maubert, Y.; Harmelin, Y.; Boukari, F.; Ambrosetti, D.; Lacour, J.-P.; Passeron, T. Differences in Visible Light-Induced Pigmentation According to Wavelengths: A Clinical and Histological Study in Comparison With UVB Exposure. Pigment. Cell Melanoma Res. 2014, 27, 822-826. [CrossRef]

38. Falcone, D.; Uzunbajakava, N.E.; van Abeelen, F.; Oversluizen, G.; Peppelman, M.; van Erp, P.E.J.; van de Kerkhof, P.C.M. Effects of blue light on inflammation and skin barrier recovery following acute perturbation. Pilot study results in healthy human subjects. Photodermatol. Photoimmunol. Photomed. 2018, 34, 184-193. [CrossRef]

39. Weinstabl, A.; Hoff-Lesch, S.; Merk, H.F.; Von Felbert, V. Prospective Randomized Study on the Efficacy of Blue Light in the Treatment of Psoriasis Vulgaris. Dermatology 2011, 223, 251-259. [CrossRef] [PubMed]

40. Kleinpenning, M.; Otero, M.; van Erp, P.; Gerritsen, M.; Van De Kerkhof, P. Efficacy of Blue Light Vs. Red Light in the Treatment of Psoriasis: A Double-Blind, Randomized Comparative Study. J. Eur. Acad. Dermatol. Venereol. 2012, 26, 219-225. [CrossRef]

41. Kleinpenning, M.M.; Smits, T.; Frunt, M.H.A.; Van Erp, P.E.J.; Van De Kerkhof, P.C.M.; Gerritsen, R.M.J.P. Clinical and Histological Effects of Blue Light on Normal Skin. Photodermatol. Photoimmunol. Photomed. 2010, 26, 16-21. [CrossRef]

42. Ohara, M.; Kawashima, Y.; Katoh, O.; Watanabe, H. Blue Light Inhibits the Growth of B16 Melanoma Cells. Jpn. J. Cancer Res. 2002, 93, 551-558. [CrossRef] [PubMed]

43. Ohara, M.; Fujikura, T.; Fujiwara, H. Augmentation of the Inhibitory Effect of Blue Light on the Growth of B16 Melanoma Cells by Riboflavin. Int. J. Oncol. 2003, 22, 1291-1295. [CrossRef]

44. Sparsa, A.; Faucher, K.; Sol, V.; Durox, H.; Boulinguez, S.; Doffoel-Hantz, V.; Calliste, C.-A.; Cook-Moreau, J.; Krausz, P.; Sturtz, F.G.; et al. Blue Light Is Phototoxic for B16F10 Murine Melanoma and Bovine Endothelial Cell Lines by Direct Cytocidal Effect. Anticancer. Res. 2010, 30, 143-148. [PubMed]

45. Chen, Z.; Li, W.; Hu, X.; Liu, M. Irradiance Plays a Significant Role in Photobiomodulation of B16F10 Melanoma Cells by Increasing Reactive Oxygen Species and Inhibiting Mitochondrial Function. Biomed. Opt. Express 2019, 11, 27-39. [CrossRef]

46. Maari, C.; Viau, G.; Bissonnette, R. Repeated Exposure to Blue Light Does Not Improve Psoriasis. J. Am. Acad. Dermatol. 2003, 49, 55-58. [CrossRef]

47. Pfaff, S.; Liebmann, J.; Born, M.; Merk, H.F.; Von Felbert, V. Prospective Randomized Long-Term Study on the Efficacy and Safety of UV-Free Blue Light for Treating Mild Psoriasis Vulgaris. Dermatology 2015, 231, 24-34. [CrossRef]

48. Krings, L.; Liebmann, J.; Born, M.; Leverkus, M.; Von Felbert, V. A randomized study comparing the efficacy and safety of blue light and topical vitamin D treatments for mild Psoriasis vulgaris. Trends Photochem. Photobiol. 2019, 18, 1-11.

49. Lesiak, A.; Bednarski, I.A.; Narbutt, J. Prospective 3-month study on the efficacy of UV-free blue light in mild psoriasis vulgaris treatment. Adv. Dermatol. Allergol. 2021, 38.

50. Krutmann, J.; Medve-Koenigs, K.; Ruzicka, T.; Ranft, U.; Wilkens, J.H. Ultraviolet-free phototherapy. Photodermatol. Photoimmunol. Photomed. 2005, 21, 59-61. [CrossRef]

51. Becker, D.; Langer, E.; Seemann, M.; Seemann, G.; Fell, I.; Saloga, J.; Grabbe, S.; Von Stebut, E. Clinical Efficacy of Blue Light Full Body Irradiation As Treatment Option for Severe Atopic Dermatitis. PLoS ONE 2011, 6, e20566. [CrossRef]

52. Keemss, K.; Pfaff, S.C.; Born, M.; Liebmann, J.; Merk, H.F.; Von Felbert, V. Prospective, Randomized Study on the Efficacy and Safety of Local UV-Free Blue Light Treatment of Eczema. Dermatology 2016, 232, 496-502. [CrossRef] [PubMed]

53. Ash, C.; Harrison, A.; Drew, S.; Whittall, R. A Randomized Controlled Study for the Treatment of Acne Vulgaris Using HighIntensity 414 Nm Solid State Diode Arrays. J. Cosmet. Laser Ther. 2015, 17, 170-176. [CrossRef] [PubMed]

54. Liu, G.; Pan, C.; Li, K.; Tan, Y.; Wei, X. Phototherapy for Mild to Moderate Acne Vulgaris with Portable Blue and Red Led. J. Innov. Opt. Heal. Sci. 2011, 4, 45-52. [CrossRef]

55. Kawada, A.; Aragane, Y.; Kameyama, H.; Sangen, Y. An open study and in vitro investigation of acne phototherapy with a high-intensity, enhanced, narrowband, blue light source. J. Am. Acad. Derm. 2005, 52, P14. [CrossRef]

56. Noborio, R.; Nishida, E.; Kurokawa, M.; Morita, A. A New Targeted Blue Light Phototherapy for the Treatment of Acne Photodermatol. Photoimmunol. Photomed. 2007, 23, 32-34. [CrossRef] [PubMed]

57. Ammad, S.; Gonzales, M.; Edwards, C.; Finlay, A.Y.; Mills, C. An Assessment of the Efficacy of Blue Light Phototherapy in the Treatment of Acne Vulgaris. J. Cosmet. Dermatol. 2008, 7, 180-188. [CrossRef]

58. Omi, T.; Bjerring, P.; Sato, S.; Kawana, S.; Hankins, R.; Honda, M. 420 Nm Intense Continuous Light Therapy for Acne. J. Cosmet. Laser Ther. 2004, 6, 156-162. [CrossRef] [PubMed]

59. Gold, M.H.; Andriessen, A.; Biron, J.; Andriessen, H. Clinical efficacy of self-applied blue light therapy for mild-to-moderate facial acne. J. Clin. Aesthet. Derm. 2009, 2, 44-50. [CrossRef]

60. Morton, C.A.; Scholefield, R.D.; Whitehurst, C.; Birch, J. An Open Study to Determine the Efficacy of Blue Light in the Treatment of Mild to Moderate Acne. J. Dermatol. Treat. 2005, 16, 219-223. [CrossRef] [PubMed] 
61. Greaves, A.J. The Effects of Narrowbands of Visible Light Upon Some Skin Disorders: A Review. Int. J. Cosmet. Sci. 2016, 38, 325-345. [CrossRef] [PubMed]

62. Jung, Y.R.; Kim, S.J.; Sohn, K.C.; Seo, Y.J.; Lee, Y.; Whang, K.U.; Kim, C.D.; Lee, J.H.; Im, M. Regulation of Lipid Production by Light-Emitting Diodes in Human Sebocytes. Arch. Dermatol. Res. 2015, 307, 265-273. [CrossRef] [PubMed]

63. Queirós, C.; Garrido, P.M.; Silva, J.M.; Filipe, P. Photodynamic Therapy in Dermatology: Beyond Current Indications. Dermatol. Ther. 2020, 33, 1-7. [CrossRef]

64. Babilas, P.; Schreml, S.; Landthaler, M.; Szeimies, R.-M. Photodynamic Therapy in Dermatology: State-of-the-Art. Photodermatol. Photoimmunol. Photomed. 2010, 26, 118-132. [CrossRef] [PubMed]

65. Darlenski, R.; Fluhr, J.W. Photodynamic Therapy in Dermatology: Past, Present, and Future. J. Biomed. Opt. 2012, 18, 061208. [CrossRef] [PubMed]

66. Kostović, K.; Pastar, Z.; Ceović, R.; Mokos, Z.B.; Buzina, D.S.; Stanimirović, A. Photodynamic Therapy in Dermatology: Current Treatments and Implications. Coll. Antropol. 2012, 36, 1477-1481. [PubMed]

67. Wen, X.; Li, Y.; Hamblin, M.R. Photodynamic therapy in dermatology beyond non-melanoma cancer: An update. Photodiagnosis Photodyn. Ther. 2017, 19, 140-152. [CrossRef]

68. Castano, A.P.; Demidova, T.N.; Hamblin, M.R. Mechanisms in Photodynamic Therapy: Part one-photosensitizers, Photochemistry and Cellular Localization. Photodiagn. Photodyn. Ther. 2004, 1, 279-293. [CrossRef]

69. Castano, A.P.; Demidova, T.N.; Hamblin, M.R. Mechanisms in photodynamic therapy: Part two-cellular signaling, cell metabolism and modes of cell death. Photodiagn. Photodyn. Ther. 2005, 2, 1-23. [CrossRef]

70. Klein, A.; Babilas, P.; Karrer, S.; Landthaler, M.; Szeimies, R.-M. Photodynamic Therapy in Dermatology-An Update 2008. J. Dtsch. Dermatol. Ges. 2008, 6, 839-845. [CrossRef]

71. Piacquadio, D.J.; Chen, D.M.; Farber, H.F.; Fowler, J.F., Jr.; Glazer, S.D.; Goodman, J.J.; Hruza, L.L.; Jeffes, E.W.B.; Ling, M.R.; Phillips, T.J. Photodynamic Therapy With Aminolevulinic Acid Topical Solution and Visible Blue Light in the Treatment of Multiple Actinic Keratoses of the Face and Scalp: Investigator-Blinded, Phase 3, Multicenter Trials. Arch. Derm. 2004, 140, 41-46. [CrossRef] [PubMed] 